STUDIA PRAWNO-EKONOMICZNE, T. CXIX, 2021

PL ISSN 0081-6841; e-ISSN 2450-8179 $\quad$ s. 163-168

https://doi.org/10.26485/SPE/2021/119/9

Marek KURYŁOWICZ*

iD https://orcid.org/0000-0001-5339-5489

\title{
KRZYSZTOF SZCZYGIELSKI, PRAWA ANTYCZNE W PIŚMIENNICTWIE POLSKIM W LATACH 1900-1945, WYD. TEMIDA 2, BIAŁYSTOK 2020, SS. 311, ISBN: 978-83-65696-73-1
}

Książka K. Szczygielskiego jest opracowaniem bibliograficznym. Dołącza do wcześniejszych publikacji Marii Zabłockiej (por. M. Kuryłowicz, Dorobek oraz plany badawcze polskiej romanistyki. W zwiazku z praca M. Zabłockiej, Romanistyka polska po II wojnie światowej, CPH 55, 2003, z. 1, s. 441-457; tenże: Maria Zabłocka, Romanistyka polska w pierwszym dziesięcioleciu XXI wieku, Liber, Warszawa 2013, ss. 209, CPH 67, 2015, s. 403-407). Kontynuowana jest również w Internecie Bibliografia powojennej romanistyki polskiej, prowadzona na bieżąco przez prof. Marię Zabłocką. W sumie więc polski czytelnik dysponuje obecnie pełną bibliografią w zakresie praw antycznych w Polsce od roku 1900 do 2010.

Wydawnictwa tego typu zajmują zwykle dalsze miejsce w głębi bibliotecznych półek i tam pokrywają się patyną, ponieważ już mało kto czyta publikacje dotyczące praw antycznych, a bibliografie tym bardziej odchodzą niestety w zapomnienie. Pisałem w tej kwestii w 2009 r.

Trudności niektórych młodych kandydatów do kariery naukowej, nie tylko zresztą w prawie rzymskim, najczęściej wynikają, moim zdaniem, z braku oczytania. A gdy podejmują już konkretny temat badawczy, to zawężają się na ogół do lektury prac ściśle z nim związanych. Potem stają bezradni, bo innej literatury na bieżąco nie przeglądali, a do dawniejszej też nie sięgali. A więc pozostaje niezmiennie aktualna rada: czytać, czytać i czytać. Nie tylko zresztą z prawa rzymskiego, także z historii starożytnej i całego antyku... (Quid leges sine moribus? Studia nad prawem rzymskim ..., Lublin 2009, s. 21).

* Prof. dr hab., profesor emerytowany, UMCS, Wydział Prawa i Administracji, Katedra Doktryn Polityczno-Prawnych i Prawa Rzymskiego; e-mail: mekur@wp.pl 
Obecnie dodałbym: nie znają również i nie korzystają z bibliografii, które stanowią jedno z podstawowych narzędzi warsztatu pracownika naukowego, zwłaszcza w dziedzinie nauk humanistycznych i społecznych. A gdy doktoranci pytają, od czego zacząć prace nad nowym tematem, mogę podpowiedzieć, że m.in. od czytania bibliografii.

Bibliografie są tu nieocenioną pomocą i już w tym można widzieć podstawową wartość omawianej książki K. Szczygielskiego, zwłaszcza że jest ona ułożona systematycznie i przejrzyście. Obejmuje dzieła ogólne (rozdział I), prawo w starożytnym Egipcie (II), prawa klinowe w starożytnej Mezopotamii (III), prawo starożytnego Izraela (IV) oraz prawa w starożytnej Grecji (V). Rozdział VI to już obszerniejsze zestawienie publikacji z zakresu prawa rzymskiego, ułożone według osobnej wewnętrznej systematyki. Całość poprzedza Wstęp (s. 23), a zamykają Zakończenie (s. 279-282), Bibliografia (do omawianego dzieła, s. 283-286) oraz ważny dla całości Indeks osobowy (s. 293-311). Należy podzielić nadzieje Autora, że jego książka

\footnotetext{
będzie wartościową pomocą nie tylko dla tych, którzy naukowo zajmują się badaniem starożytności, ale również dla wszystkich innych osób zainteresowanych pogłębieniem swojej wiedzy na temat różnych zagadnień natury prawnej świata antycznego oraz świadectwem wkładu polskich uczonych do międzynarodowego dorobku w zakresie studiów nad prawami antycznymi (s. 31).
}

Dodać należy, że przytoczone w omawianej książce pozycje bibliograficzne są szczegółowe i staranne, informują nie tylko o polskich publikacjach, lecz również o pozycjach zagranicznych (obcojęzycznych), do których sporządzane były w Polsce komentarze i noty recenzyjne. Co ciekawe, informowano w ten sposób polskiego czytelnika nie tylko o książkach i monografiach, lecz również o treści artykułów zamieszczonych w naukowych czasopismach lub np. w innych wydawnictwach (np. bibliografiach i encyklopediach). Z tych względów należy już tutaj stwierdzić, że opracowanie K. Szczygielskiego jest pożyteczną i ciekawą, a miejscami wręcz fascynującą lekturą.

Do tych objaśnień i informacji trzeba dodać kilka komentarzy. Otóż trafnie zauważa Autor „wszystkich, którzy naukowo zajmują się badaniem starożytności" (patrz wyżej). Wśród autorów przytoczonych w książce publikacji są bowiem zarówno historycy prawa rzymskiego i innych praw antycznych, jak i historycy starożytności, filolodzy klasyczni i kanoniści. Dobrze byłoby zatem wymienić specjalności naukowe ważniejszych przynajmniej i częściej przywoływanych w książce autorów, aby mniej zorientowany czytelnik mógł odróżnić np. filologa klasycznego Stanisława Witkowskiego od Franciszka Witkowskiego, autora przekładu instytucji prawa rzymskiego Karola Czyhlarza 
na język polski (s. 133), a także innych filologów od np. historyków czasów antycznych (jak choćby Ludwik Piotrowicz, Tadeusz Wałek-Czernecki i Zdzisław Zmigryder-Konopka). A wymienionych od specjalistów w zakresie praw antycznych jak np. Adolf Berger czy Rafał Taubenschlag. Wśród prawników są obok historyków prawa także cywiliści (Roman Longchamps de Bérier) oraz znawcy prawa karnego (Juliusz Makarewicz). Zauważyć też można historyków dziejów ojczystych (osobliwa postać Bronisława Geberta) czy historyka prawa polskiego Przemysława Dąbkowskiego. Tu także Stanisław Estreicher, historyk prawa i wybitny bibliograf. Byłoby zatem bardzo pożyteczne, aby w Indeksie osobowym opatrzyć niektóre nazwiska jednozdaniowym choćby objaśnieniem specjalizacji naukowej wymienionego autora, co wprowadziłoby pożyteczne dla czytelnika uzupełnienie biograficzne.

Inne stwierdzenie dotyczy „wszystkich innych osób, zainteresowanych pogłębianiem swej wiedzy”. W całym przeglądzie bibliograficznym zauważyć można wielość autorów różnej pozycji i usytuowania. Obok uczonych (profesorów uniwersyteckich) można zauważyć osoby z doktoratami, ale także spore rzesze nauczycieli szkół powszechnych oraz miłośników wiedzy o starożytności, aktywnych w lokalnych towarzystwach naukowych, skupiających osoby o różnych zawodowych karierach i zamiłowaniach. Przykładem może być osoba Eugeniusza Barwińskiego (1874-1947), polskiego historyka, wydawcy źródeł oraz sekretarza Towarzystwa Historycznego i dyrektora archiwum we Lwowie, później w Krakowie. W omawianej książce jest cytowany obficie (40 razy), bez jednak jakiejkolwiek wzmianki, czym zajmował się zawodowo. Innym przykładem jest Stanisław Pawłowski, autor rozprawki pod tytułem Wpływ chrześcijaństwa na prawodawstwo Konstantyna Wielkiego, ogłoszonej w Sprawozdaniu Dyrekcyi C.K. Gimazyum z wykładowym językiem polskim w Stanisławowie za rok szkolny 1906/1907, Stanisławów 1907 (37 stron). Potwierdza się więc obserwacja o ruchu naukowym w lokalnych towarzystwach oraz w szkołach w XIX oraz początkach XX w. Takie notki o dawnych naukowych próbach i osiągnięciach wypełniają bibliografię K. Szczygielskiego, a można w nich znaleźć wiele interesujących informacji, podpowiedzi oraz inspiracji badawczych. Ciekawostką może być tutaj okoliczność, że w 2020 r. na Wydziale Prawa i Administracji UMCS obroniona została rozprawa doktorska o humanitas w ustawodawstwie cesarza Konstantyna (B. Zalewski), jakby dalekie echo wymienionej rozprawki S. Pawłowskiego.

$\mathrm{Z}$ drugiej strony, omawiana bibliografia zawiera sporo (zwłaszcza w kategorii Dzieła ogólne, ss. 35-49) podręczników szkolnych dla uczniów lub seminariów nauczycielskich, opowiadań z dziejów dla młodzieży, krótkich historii 
w streszczeniu lub w zarysie. Niekiedy wydawane przez znanych nauczycieli i pedagogów (np. H. Wernic, s. 37), niekiedy bezimiennie (tamże - Jazłowiec 1905-1906), ale zdarzają się też informacje niejasne. Tak np. w pozycji: A. Semkowicz, Opowiadania z dziejów powszechnych dla niższych klas szkót gimnazjalnych i realnych (cz. I, wyd. 2, Lwów 1901) nie wiadomo, o którego Aleksandra Semkowicza chodzi, ponieważ było ich dwóch. Pierwszy - mediewista i profesor Uniwersytetu Lwowskiego, w 1901 roku miał lat 11; drugi zaś, starszy od swojego stryjecznego bratanka o 5 lat, był introligatorem artystycznym. Zapewne jest gdzieś błąd (może powinno być 1911 zamiast 1901?), ale potwierdza się potrzeba objaśnień co do cytowanych osób.

Aktualne inspiracje pojawiają się w odniesieniu do niektórych wymienionych w omawianej bibliografii historyków praw antycznych. Sam Autor (K. Szczygielski) zapowiada studium o zapomnianym już dzisiaj badaczu prawa babilońskiego Antonim Szaniawskim (zm. w 1909 r.; patrz s. 76, przypis 13). $\mathrm{Na}$ opracowanie oczekuje jednak również sylwetka naukowa Adolfa Bergera, uznawanego za najwybitniejszego romanistę polskiego (W. Litewski, Słownik encyklopedyczny prawa rzymskiego, Kraków 1998, s. 293), choć określany jest również jako uczony austriacko-amerykański, z rozległym dorobkiem i bogatym życiorysem. Światową drogę przebył również Rafał Taubenschlag, którego uczniami byli profesorowie Henryk Kupiszewski (Warszawa) i Józef Mélèze-Modrzejewski (Warszawa-Paryż). Ponadto Stanisław Wróblewski, romanista i cywilista, określany zaszczytnym mianem ,polskiego Papiniana”, a także Franciszek Bossowski, romanista wileński o znaczącym dorobku naukowym. Od dawna zainteresowanie wzbudza sylwetka lwowskiego profesora Leona Pinińskiego, którego dorobek naukowy został ostatnio objęty badaniami w Katedrze Prawa Rzymskiego Uniwersytetu Łódzkiego. Są to wyraźne luki w biografistyce polskiej romanistyki, a jednocześnie dobre wskazówki dla prac nad wzbogaceniem jej dziejów (szczegóły patrz s. 259-277).

Ocenia także Autor stopień zainteresowania poszczególnymi działami prawa rzymskiego. Po cieszącej się większym zainteresowaniem historii źródeł, przychodzi stwierdzenie, że „Zagadnienia związane z prawem osobowym i czynnościami prawnymi nie przyciągały większej uwagi polskich badaczy" (s. 175). Wynikało to prawdopodobnie z przejęcia przez pandektystów obszaru czynności prawnych, które w prawie rzymskim antycznym nie znajdowały swojego wyraźnego miejsca. Podobnie ius quod ad personas pertinet (G.1,8-9) obejmowało w rzymskim ujęciu zarówno prawo osobowe, jak i rodzinne. Prawo osobowe znalazło się w systematyce pandektowej w części ogólnej, po której umieszczone zostało prawo rodzinne (M. Kuryłowicz, R. Świrgoń-Skok, 
Systematyka polskich podręczników prawa rzymskiego, w: Toruń 2018, s. 140-142). Poważniejszą uwagę polskich badaczy znalazły wymienione prawo rodzinne oraz prawo rzeczowe. Jednym z głównych kierunków badań było zawsze prawo obligacyjne (s. 192), czego nie można powiedzieć o prawie spadkowym. Niewielkie zainteresowanie rzymskim prawem spadkowym utrzymało się również w okresie powojennym (s. 198, przypis 165). U podłoża leżała być może jego nadmierna drobiazgowość oraz znowu odmienne ulokowanie w systematyce Instytucji (w dziale res jako uniwersalny sposób nabycia własności), w odróżnieniu od pandektystyki, gdzie prawo spadkowe zostało umieszczone na końcu jako logiczne zamknięcie systemu prawa prywatnego (patrz wyżej M. Kuryłowicz, R. Świrgoń-Skok, s. 147-148; M. Kuryłowicz, Prawo spadkowe $w$ systematyce rzymskiego prawa prywatnego, w: Rozprawy z prawa prywatnego oraz notarialnego. Księga dedykowana profesorowi Maksymilianowi Pazdanowi, Warszawa 2014, s. 170-180). W przedstawionym przez Autora okresie rzymskie prawo karne (z procesem karnym włącznie) nie miało jeszcze wyraźnej pozycji wśród kierunków badawczych (jak to się stało w drugiej połowie XX w.), znacznie więcej miejsca zajmowało wówczas prawo publiczne ujawniające się w publikacjach zarówno romanistów, jak i historyków starożytnego Rzymu oraz filologów klasycznych. W sumie interesujący materiał do dziejów polskiej romanistyki.

W Zakończeniu wyróżnia Krzysztof Szczygielski trzy zasadnicze okresy w analizowanym przedziale czasowym, każdy w odmiennych warunkach politycznych, gospodarczych i społecznych. Wyróżnił też ośrodki naukowe, wśród których prym wodziły uniwersytety galicyjskie, na których wykształcili się kolejni romaniści polscy pierwszej połowy XX w. Uczeni pracujący w systemie rosyjskiego szkolnictwa wyższego nie pozostawili po sobie następców. Najbardziej owocny w piśmiennictwo był okres międzywojenny z wyzwolonym spod zaborów państwem polskim. Wśród zrelacjonowanych publikacji najwięcej miejsca zajmuje prawo rzymskie, aczkolwiek stosunkowo mała była liczba przekładów tekstów źródłowych z prawa rzymskiego, zwłaszcza wobec opublikowanych wówczas tłumaczeń Kodeksu Hammurabiego (D.H. Müller, Stryj 1905; A. Szaniawski) oraz prawa staroasyryjskiego (M. Schorr, Lwów 1923). Odnotowuje Autor również naukowe kontakty z uczonymi włoskimi, spośród których Pietro Bonfante, Salvatore Riccobono i Pietro De Francisci otrzymali tytuły doktorów honoris causa polskich uniwersytetów (Warszawskiego i Wileńskiego). Dodać do nich można profesorów Edoardo Volterra oraz Luigi Labruna uhonorowanych $\mathrm{w}$ ten sposób w powojennych latach przez Uniwersytet Jagielloński, Uniwersytet Warszawski oraz Uniwersytet Mikołaja Kopernika 
w Toruniu (W. Wołodkiewicz, Romaniści włoscy - doktorzy honoris causa uniwersytetów polskich, Przegląd Historyczny 1996/87/2, s. 409-422). Można jednak przy tym postawić pytanie o przyczyny braku doktoratów honoris causa dla polskich romanistów.

Ogólna ocena Autora polskiej romanistyki w świetle zebranej bibliografii jest jednak bardzo pozytywna: „Podsumowując dorobek polskich badaczy w zakresie praw antycznych, powstały w latach 1900-1945, stwierdzić należy, że jest to znaczący wkład zarówno do historii nauki polskiej, jak też nauki światowej”. $\mathrm{Z}$ tą oceną należy się zgodzić, a K. Szczygielskiemu wyrazić zasłużone uznanie za interesującą i wartościową książkę z bogatą panoramą polskich badań nad prawami antycznymi ze szczególnym uwzględnieniem prawa rzymskiego. 